\section{Dušan Jerotijević ${ }^{1}$}

Živanka Miladinović Bogavac, ${ }^{2}$

University Union Nikola Tesla,

Faculty of Business and Law

Belgrade Serbia

\section{Ljubiša Stamatović3}

Ministry of Foreign Affairs of the Republic of Serbia

Belgrade Serbia
SCIENTIFIC REVIEW ARTICLE

DOI: 10.5937/ekonomika2004095J

Received: May, 08. 2020.

Accepted: November, 16. 2020.

\title{
CUSTOMS WAR OF THE KINGDOM OF SERBIA AND THE HABZBURG MONARCHY AT THE BEGINNING OF THE 20th CENTURY
}

\begin{abstract}
After gaining independence at the Berlin Congress, Serbia became the center around which all the surrounding Serbs gathered, seeking final liberation and unification. The great difficulty for a small Serbia was the Austro-Hungarian Empire, which in every way was trying to influence the Serbian internal and foreign policy. In doing so, she succeeded to a large extent during the reign of King Milan, even after his abdication, until the beginning of the XX century. The change in the throne after the May uprising led to the emancipation of Serbia from the influence of the Austro-Hungarian Empire and the influence of other powers, in particular France and Russia. On the other hand, Serbia is increasingly independent in foreign policy and tries to connect with other Balkan states as if it economically strengthens to carry out a national unification mission. That is why the Austro-Hungarian conflict with Serbia on the economic plane, the Customs War, was inevitable. At the same time, this conflict has shown the strength and weaknesses of both countries. Serbia's victory in the Customs War showed her great economic rise, and Austro-Hungary became its fatal enemy.
\end{abstract}

Key words: Serbia, Austro-Hungarian, Customs War, national unification, Russia, France.

JEL classification: G-18, H-2, F-51

\section{ЦАРИНСКИ РАТ КРАЉЕВИНЕ СРБИЈЕ И ХАБЗБУРШКЕ МОНАРХИЈЕ НА ПОЧЕТКУ 20. ВЕКА}

\footnotetext{
Апстракт

Србија је после добијања независности на Берлинском конгресу постала иентар око кога су се окупьали сви околни Срби желећи коначно ослобођење

${ }^{1}$ dusanjerotijevic@gmail.com, ORCID ID 0000-0003-4252-7487

${ }^{2}$ zivankamiladinovic@gmail.com, ORCID ID 0000-0003-2860-3578

${ }^{3}$ ljubisastamatovic@gmail.com, ORCID ID 0000-0003-0477-8277
} 
и уједињење. Велика тешкоћа за малу Србију је била Аустроугарска, која је на сваки начин настојала, да утиче на српску унутрашюу и спољну политику. У томе је успевала у великој мери за време владавине краља Милана, па и после юегове абдикаиије, све до почетка XX века. Промена на престолу после мајског преврата довела је до еманиипована Србије од утицаја Аустроугарске и уплива других сила, посебно Франиуске и Русије. Са друге стране Србија је све независнија у спољној политици и покушава да се повеже са другим балканским државама као и да економски ојача како би спровела мисију националног уједињења. Због тога је сукоб Аустроугарске са Србијом на економском плану, Царински рат, био неизбежан. Истовремено овај сукоб је показао снагу и слабости обе државе. Победа Србије у Царинском рату показала је юен велики привредни успон, а Аустроугарска је постала њен смртни непријатељ.

Кључне речи: Србија, Аустроугарска, Царински рат, национално уједињење, Русија, Франиуска.

\section{Introduction}

After the May coup, the political center of gravity shifted from the court to the assembly and political parties. Introducing civil parliamentarism in Serbia has not been easy, nor has it gone without opposition. In Serbian political life, not only political parties but also background currents that used the court clashed with each other. The intertwined political situation enabled not only all kinds of political alliances and combinations with market movements, but also provided an opportunity for Austrian diplomacy to intervene in Serbia's internal political debates. That is why the internal political situation in Serbia will be of the greatest importance in the period preceding the Customs War.

Since 1903, Serbian foreign policy has abandoned the earlier fluctuations between Austro-Hungary and Russia and joined the western bloc of major capitalist powers, together with Russia (with which strategic interests linked it) first to France and then to England. The reasons for this policy are multiple. Due to the activation of the national program(Lopandić, 2010.p.166-164). in Serbia after 1903, a conflict with AustroHungary was inevitable, and therefore with Germany behind it. The program that formed the core of foreign policy after 1903 had two blades, towards Bosnia and Herzegovina and the southern regions (areas south of Shkodra, the area of old Raška, Kosovo and Metohija and Old Serbia with Vardar). If she was not allowed to move towards Bosnia and Herzegovina out of fear of Austro-Hungary, she received a stronger expression of action towards the southern regions. Vienna did its best to thwart Serbia's intentions, primarily by trying to separate it from its natural allies, Bulgaria and Greece, as well as the other Serbian state, Montenegro. Economically, Serbia was trying to break free of the dominant Austro-Hungarian influence, and so there was an increase in imports from Russia at the beginning of the 20th century (Popović 1, 2007. p. 65). 


\section{Serbia just before the customs war and the reason for it}

The Serbian-Bulgarian economic rapprochement was mutual economic insurance: Serbia to Austria-Hungary, Bulgaria to Turkey. In alliance with Bulgaria, Serbia gained economic independence from the Habsburg Monarchy, Bulgaria gained the conditions for political and economic emancipation from Turkey and the prospect of breaking through Central European markets through Serbia. The conclusion of the Customs Union was linked to a number of secondary issues. Serbia and Bulgaria were facing a new trade agreement with Austria-Hungary, and Serbia was more dependent on it (Đorđević, 1962. p. 125). Also, Bulgaria saw in the Customs Union with Serbia a means of freeing up capitulations and concluding a veterinary convention with the Habsburg Monarchy, while Serbia was obliged by the provisions of the treaty with Vienna to prevent any livestock trade with Bulgaria, as this was a condition of its veterinary convention with Austria-Hungary, and any contrary provision entering the Customs Union would withdraw Vienna's penalties This 1905 Serbian-Bulgarian treaty has caused much debate. According to one, it was an ordinary trade agreement which for political reasons was given the name of the customs union, where this view was represented by the Viennese and English cabinets, while according to the other, the contract represented the customs union in a broad sense, because it did not contain all the elements that were needed by that alliance. It was at this time that Serbia negotiated a new trade agreement with Austria-Hungary. The old trade agreement between the two countries was valid until January 1, 1904, with a one-year notice period. Considering that her contract violated her interests, Austro-Hungary terminated trade negotiations with Serbia and then declared her a customs war (Đorđević, 1962. p. 127).

The conditions imposed by Austria-Hungary were inappropriate in the relations between the two sovereign states. Namely, Serbia is conditioned to buy artillery weapons from Austro-Hungarian factories, and not from those countries that had the most favorable offer for Serbia. The Serbian government remained firm in its position not to accept these proposals from the Viennese government, as it could become a permanent practice in Austro-Hungarian relations with Serbia (Ćorović, 1997. p. 607).

News of the Customs War in Serbia was received with enthusiasm because the intentions of the Habsburg Monarchy to crush Serbia were so obvious and politically oriented that any indulgence would be characterized as treason and the Habsburg Monarchy declared the culprit. The Serbian government, with great support from the Assembly and much of the public, responded to the Austro-Hungarian pressure by countermeasures.

The internal and foreign political difficulties that the Habsburg Monarchy was in, caused the leaders to fear for its future and integrity. A way out of this situation was found in order to create a new conception of political development by helping new people in the most responsible places, which would preserve the integrity of the Habsburg Monarchy and at the same time raise its reputation in the eyes of Europe. Changes to foreign policy institutions were to consolidate the situation in the country, which would leave some hands on the military and diplomacy in the game of great powers for hegemony in the Balkans.

In order to achieve the foreign policy goals, consolidation within the Habsburg Monarchy was necessary. To this end, the solution to the South Slavic problem was to be 
reorganized by reorganizing the South Slavic regions by creating from the inhabitants of Croatia, Slovenia, Dalmatia and Bosnia and Herzegovina, a South Slavic group centered in Zagreb, which was included in the framework of Hungary. This would make Hungary more engaged in settling national movements among the South Slav nations.

After the Habsburg Monarchy concluded that Serbia had secured political emancipation through its economy, it decided to provide transport and strategic advantage in the Balkans instead of trade. When this policy encounters resistance from European diplomacy, especially Russia, the Habsburg Monarchy will declare annexation of Bosnia and Herzegovina (Popović 2, 2007. p. 160-161). In this way, the Austro-Hungarian policy towards Serbia was reflected in three successive offensives: economic or customs war, transport in the New Pazar railway project, and political or annexation of Bosnia and Herzegovina.

\section{Customs war}

When Serbia wanted to enter into a customs union with Bulgaria, AustriaHungary declared it a Customs War in 1906, believing that it would destroy Serbia with the economic crisis. It is especially important that a year earlier a draft customs union agreement between Serbia and Bulgaria was signed. Although this project should not have been made public, Bulgaria did so to scare Turkey (Jovanović, 1929. p. 89-95). This is just one example of cooperation with new partners and new Serbian trade routes. However, Serbia is winning the Austro-Hungarian Criminal War and developing its industry. Trade has developed faster than population growth in Serbia.

During this period, Serbia had a number of extremely capable politicians and intellectuals in the government. In addition to Pasic and Milovan Milovanović, Lazar Paču, the Minister of Finance, although a doctor by profession, had special importance. He distinguished himself by being an honest and honorable man whose main aim was to protect and empower the Treasury. In this customs war, his role played an exceptional, perhaps crucial, role.

In order to exert political pressure on Serbia, the Viennese government would from time to time ban the import of live pigs, a very important Serbian export item (Pržić, 1939. p. 137). For these reasons, the customs press, which lasted from July 1906 to July 1910, was ironically called the "pig war" (Jerotijević and Jerotijević, 2016. p. 53).

The difficult circumstances in which Serbia found itself were closely followed by a French financial inspector on a mission in Belgrade and a representative of France. Also, there was one German representative in the Administration of the Serbian State Monopoly in Belgrade, Joseph Simon, who was technically a "mute observer" sent to make sure that the Serbian government fulfills its obligations to creditors. The utterly irrational exploitation of the country's agricultural assets, which are transported to the plains of Hungary for safe, easy, though not lucrative sales, he wrote, is exacerbated by the fact that many Serbian producers are often unaware of the supply and current prices on the world market and which does not have enough docks and warehouses. Because of the latter, manufacturers were often forced to sell their goods at the price offered to them.

The Serbian government responded by raising slaughterhouses to export meat products rather than livestock. In this way Serbia did not export raw materials, live cattle, 
but we can say semi-finished products and products, which gave even higher quality to its exports (Sforca, 1991.p.99). The financial negotiations were successfully led by Lazar Paču, who defended Serbia's fiscal stability during the customs war and beyond.

The Serbian government paid an advance of 200,000 dinars to the Joint Stock Company, and this in return obliged them to buy up to ten thousand pigs for export at the price of 80 pairs per kilogram and to pay the village sellers in cash. By the end of October 1906, the company had exported two hundred tons of fat, bacon, ham and other meat products to Algeria, Marseille, Bordeaux, Hamburg, and by the end of the year, 18,000 pigs had been slaughtered and most of it was processed into pork for export.

The government has been equally successful in organizing the export of prunes and jam (Cvijić, 1987.p.166). She indicated to the peasants that there were other markets for these products and instructed special inspectors to encourage the peasants to adopt better procedures for sorting, preparing and packaging their products. Official newspapers have begun to report on stocks and prices in the world. Thanks to this, the farmers were able to increase their prices by about 20 percent. Total exports of fruit and fruit products in 1906 rose to 65,000 tonnes, up from an average of 57,000 tonnes a year earlier.

Greater difficulties were encountered in organizing cattle exports, but in an effort to overcome this obstacle, the government sent special representatives to Genoa, Thessaloniki, Piraeus and Alexandria. She published special brochures and published reports on the cattle trade in her official newspaper. In addition, it granted certain concessions to the Serbian Export Bank to encourage it to accept export of cattle to Genoa and Alexandria. By the end of 1906, more than 3,000 head of cattle had been purchased for export, and 1,500 had already been exported.

The value of Serbia's exports in 1906, despite the customs war, was about the same as in the previous year (Stojanović, 2011. p. 7).

Table 1. Exports of Serbia from 1905 to 1907 in French franks

\begin{tabular}{|l|c|c|c|}
\hline \multicolumn{1}{|c|}{ EXPORT COUNTRIES } & 1905. & 1906. & 1907. \\
\hline Austro-Hungarien & 64.712 .000 & 30.032 .000 & 12.932 .000 \\
\hline Germany & 2.116 .00 & 19.053 .000 & 32.925 .000 \\
\hline Belgium & 323.100 & 6.259 .000 & 13.010 .000 \\
\hline England & 0 & 65.560 & 2.337 .000 \\
\hline Other countries & 4.844 .900 & 16.194 .440 & 20.287 .000 \\
\hline Total & 71.096 .000 & 71.604 .000 & 81.491 .000 \\
\hline
\end{tabular}

It should be noted that before the Customs War, Serbia exported large quantities of goods, mainly raw materials and especially live cattle. It should only be noted that during that period Austro-Hungary was the main intermediary in this trade. For example, according to the Serbian Ministry of Commerce, the value of exports to Austria-Hungary from 1899 to 1905 was RSD 396 million, but 203 million, or more than half, were reexported to other countries, especially Germany and Belgium.

Of particular importance for the outcome of the Customs War was the issue of transport, that is, the transportation of goods from Serbia to foreign markets. Serbia, with the support of its neighbors (Bulgaria and Romania), diverted exports of its goods by water, the Danube, towards the Black Sea, and rail via Bulgaria to Constantinople. 
Serbia has established new trade links. The Main Trade Agency was established in Belgrade, establishing trade links with 66 foreign representative offices from different parts of Europe from Stockholm and Amsterdam to Zurich and Moscow (Jerotijević, 2006. p. 105). In 1907, Serbia established 13 trade offices from Alexandria to London (Jerotijević, 2006. p. 105). Considering that Serbia did not experience an economic downturn in the customs war, Austro-Hungarian Foreign Minister von Erental proposed negotiations to Nikola Pašic, who visited Vienna in May 1907. The following year a trade agreement was signed between the two countries, but due to the crisis in the work of the Serbian Assembly, the treaty was confirmed after the new assembly elections on 18 August 1908 (Jerotijević, 2006. p. 106). This contract will not have a longer term because soon the "annexation crisis" about Bosnia and Herzegovina occurred. This crisis almost led to a war between Serbia and Austria-Hungary. As the Austro-Hungarian longterm occupation turned into annexation of $\mathrm{BiH}$, there was great dissatisfaction with the Serb people on both sides of the Drina River. However, the great powers were pushing for no war, which at that moment would probably be devastating for Serbia. In foreign policy, Serbia had to turn to its southern, liberated regions. In these difficult times for the Serbian nation, our diplomacy, led by Milovan Milovanović, has taken one significant step for the Serbian people, raising the Serbian question before Europe (Jovanović, 1990. p. 508-509). Milovan Milovanović, who was Foreign Minister and Prime Minister from 1908 to 1912, made a major contribution to the preparations for the final showdown with Turkey in the Balkans. The prominent Serbian scientist and politician Stojan Novaković (Novaković, 1910) also gave great support to Milovanović.

As for the Customs War, Austria-Hungary was defeated. Serbia has concluded trade agreements with major European countries, and has imported strategic raw materials, petroleum and salt from Russia and Romania. Particularly significant was the loan agreement with France in the amount of 150 million dinars, which partly related to the acquisition of weapons (Đorđević, 2012. p. 107). A new trade agreement was concluded with AustroHungary, which entered into force on 24 January 1911 (Jerotijević, 2006. p. 106).

\section{Serbia after the customs war}

The customs war has altered the economic influence of the great powers. Since 1904, they have been trying to lend to Serbia the requirements of industry. Financial engagement turns out to be a far more effective instrument for expanding political and economic spheres of influence. Thus, for some time Germany retained its leading role in the arms business, while France gradually became the main trustee of almost all Balkan countries. Since Austria-Hungary has finally been politically discredited since the Customs War and Germany has taken over the financing of its armaments, France has finally been able to win this competition by financing $79 \%$ of Serbia's loans. The Entente countries began to dominate Serbia's foreign trade (Stankovic, 1995, p. 3031).

Customs barriers imposed by Serbia in 1906 hampered the flow of goods but at the same time strongly stimulated the inflow of foreign capital. This actually meant that, as demand for industrial products was still high and protection duties disproportionately increased, many businessmen switched to making their products in Serbia as a target. 
They were then able to preserve the Serbian market while simultaneously benefiting from protectionism against foreign competition (Aleksić, 2014).

Thus, in addition to the railway construction loan, foreign financiers were increasingly involved in establishing credit institutions as well as in direct investments in private companies. The impact of the financial capital of economically more advanced countries in the economies of underdeveloped and underdeveloped countries was in fact the result of a long process of transformation of banking, which, due to the growth of industrialization, enabled the financing of various jobs in very remote geographical areas.

About seventy European banks of varying character, size and strength, which at that time made up the elite of European and therefore world banking, showed their interest in the Balkans as well. This phenomenon was of great importance for the emergence and development of private banking in Serbia itself, until the beginning of the 20th century, the entire banking system was based on a large number of small banks and savings banks, which reduced their business activity only to loans to peasants and merchants. Their fragmentation and deconcentration, with quite a small amount of available capital, made it impossible for any serious action towards faster and stronger engagement in the economic life of the country.

After the Customs War, the number of industrial enterprises, including mills, breweries and mines, increased from 100 to 465, then the number of workers increased two and a half times. When it comes to industry and mining, there was an overall growth rate of gross product from 10.75 to 24.38 dinars per capita.

Although between 30 and 35 million dinars of foreign capital had already been invested in 470 Serbian factories by the First World War, small businesses, with a small number of employees, low capital invested and small machinery equipment, still prevailed in Serbia. As early as 1908, more than half of the company employed less than 20 workers. It should be noted that in this period the dynamics of foreign trade relations accelerated and the number of countries with which Serbia maintained economic relations increased.

\section{Conclusion}

According to well-known economic historians, state support has only marginally affected the direction and pace of industrialization in Serbia. Serbia made its breakthrough to more intensive industrialization only after a four-year customs war with AustriaHungary. However, customs warfare at the same time sharpened the rivalry of the great powers in Southeastern Europe, which only a few years later turned into open conflict. This inevitably leads to the conclusion that it was precisely in the customs war that the beginning of the military conflict and the final showdown, which occurred in the First World War, arose between Serbia and Austria-Hungary. The Austro-Hungarian customs war began with the expectation that the Serbian economy and its finances would quickly collapse. This shows that this great state was not aware of the great regrouping in Europe where two blocs of great powers fought for each country regardless of its size. After the May coup, Serbia had trouble gaining the affection of some of Europe's great powers (especially the United Kingdom), but two other allies, Russia and France, were keen to help squeeze Serbia out of it and its rivals economically, above all Austria-Hungary and 
also Germany. Serbia has proven itself to be a promising economy with sufficient internal resources and diplomatic capacity to connect with some distant markets interested in its goods using new routes with the support of neighbors and large powers interested in suppressing the Austro-Hungarian economy in Serbia. The annexation of Bosnia and Herzegovina, we can say, was the Pyr victory of the Habsburg Monarchy. Serbia has been economically empowered and at the same time has received the tacit consent of Russia and France to continue national work in the southern regions. The defeat in the Austro-Hungarian Customs War was very unpleasant given that a small, neighboring country had secured its economic prosperity without its influence. We believe that this is precisely where the germ of a future conflict, the cause of which was the Sarajevo assassination, lies. Austro-Hungary could not allow the creation of a powerful and independent Serbian state, which by its very existence compromised its integrity and hindered its further penetration to the east. The military showdown was only a matter of the moment.

\section{References}

Aleksić, V. (2014). Uloga i značaj stranog kapitala u industrijalizaciji predratne Srbije. http://ebooks.ien.bg.ac.rs/71/1/va_2014_01.pdf. accessed 21.maj, 2019.

Đorđević, D. (1962). Carinski rat Austro - Ugarske i Srbije 1906. - 1911. Istorijski institut. Beograd.

Đorđević, Ž. (2012). Satiranje srpstva u 19. i 20. veku, tom I. Drasler Partner. Beograd.

Živojinović, D. (1990). Kralj Petar I Karađorđević. BIGZ. Beograd.

Jerotijević, Z. (2006). Srbija između Istoka i Zapada od Načertanija do 1914. Ljubostinja. Trstenik.

Jerotijević, Z. i Jerotijević, D. (2016). Istorija diplomatije. Fakultet za poslovnoindustrijski menadžment. Beograd.

Jovanović, J. (1929). Borba za narodno ujedinjenje 1903-1908. SKZ. Beograd.

Jovanović, S. (1990). Sabrana dela tom 11. BIGZ. Beograd.

Lopandić, D. (2010). Poslužiti svom dragom otečestvu:iz istorije diplomatije Srbije 1804-1914. Službeni glasnik. Beograd.

Mitrović, Ž. (1939). Srpske Političke stranke. Politika. Beograd.

Novaković, S. (1910). Balkanska kriza i srpsko pitanje. Štampa. Beograd.

Popović, V. (2007). Istočno pitanje. Nikola Pašić. Beograd.

Popović, N. (2007). Srbija i Carska Rusija. Službeni glasnik. Beograd.

Pržić, I. (1939). Spoljašnja politika Srbije. Politika. Beograd.

Vuković, P., Simonović, Z., \& Simonović, D. (2012). Merkatntilististička misao na prostoru zapadnog Balkana. Facta universitatis - series: Economics and Organization, 9(2), 271-282.

Stojanović, T. (2011). „Racionalizacija“ ekonomije malog prostora: Srbija i velike sile 1881 - 1914. Vlastimir Đokić, samostalni izdavač. 
Stanković, Đ. (1995). Nikola Pašić, saveznici i stvaranjeJugoslavije.Zadužbina Nikola Pašić. Zaječar.

Sforca, K. (1991). Novo delo. Beograd.

Ćorović, V. (1939). Političke prilike u Bosni i Hercegovini. Politika, Beograd.

Ćorović, V. (1997). Istorija srpskog naroda. Ars Libri. Beograd.

Hvostov, V. i Minc, I. (1949) Istorija diplomatije, tom II. Arhiv za pravne i društvene nauke. Beograd.

Cvijić, J. (1987). Govori i članci.Zavod za udžbenike i nastavna sredstva.Beograd. 
